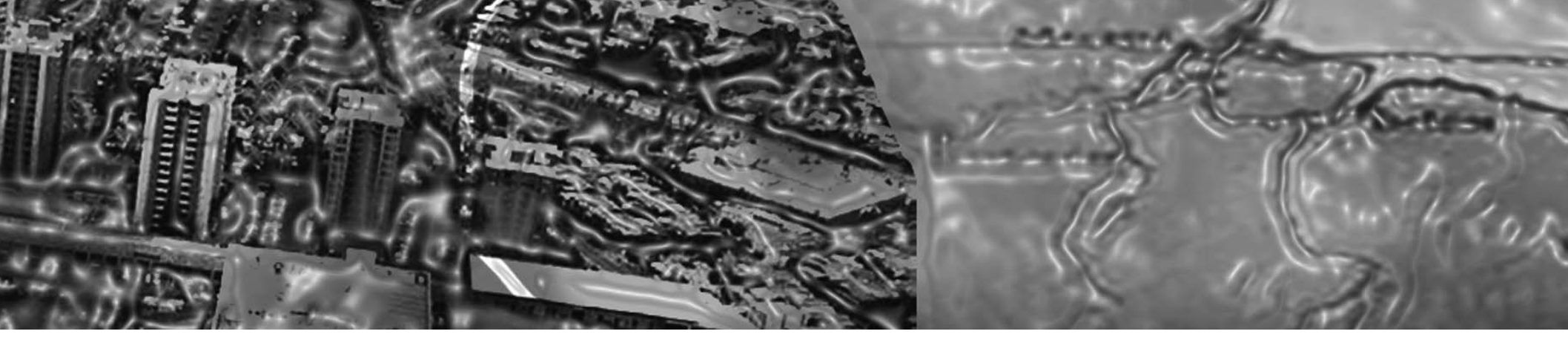

\section{BICENTENARIO URBANO EN CHILE: ¿QUÉ PUEBLO PARA QUÉ CIUDAD?}

En su origen colonial, Chile no tenía propiamente "ciudades", sino "pueblos". Es decir: comunidades de "vecinos con casa poblada" que tenían que trabajar productivamente para subsistir. $\mathrm{O}$ en las chacras, en las dehesas, en las minas, en talleres artesanales asentados en la ribera inundable del río ("chimba"), dondequiera. La complicidad vecinal era necesaria para ejercer, sobre el entorno y sobre sí mismos, una útil soberanía productiva. Sin ésta, no había vida, ni seguridad, ni futuro. Y a ella concurrían todos: los mercaderes del comercio virreinal, los encomenderos que patronizaban cuadrillas de indígenas, los chacareros de aledaño próximo, los artesanos de allende el río y los licenciados en letras, que procuraban convertir esa

\section{URBAN BICENTENARY IN CHILE: WHICH TOWN FOR WHICH CITY?}

During the colonial days there were no "cities" but "towns" in Chile. They were neighbourhoods of "peopled houses" in which residents had to work productively to survive; whether it be on small farms, pastures, mines or crafts workshops that lied on the banks of the river ("chimba"). Neighbourhood camaraderie was needed to exercise a useful productive sovereignty upon the environment and the people. The absence of this camaraderie meant the absence of life, safety and future as well. Merchants in viceregal commerce, encomenderos patronizing indigenous people, farmers, artisans and arts graduates made use of this social mechanism, 
complicidad en el auto-gobierno de todos (que, a final de cuentas, era más el cabildo abierto que la Capitanía General). La complicidad vecinal, hecha política democrática en el Cabildo local, hizo de los "pueblos" una realidad más importante que el cimiento físico de su 'ciudad'. Y en cada uno de ellos, de algún modo, esa complicidad operó como igualdad, y ésta, como democrática soberanía local. Cada "pueblo" se definió a sí mismo por tanto, antes de ser plenamente ciudad y nación, como un crepitante fogón comunitario.

Y eran cerca de 50 los "pueblos" que existían en Chile al frisar el año del nacimiento republicano: 1810. Estaban sembrados a lo largo del país, entre el río Huasco y el Bío-Bío. Distanciados unos de otros por muchas leguas en el espacio y por semanas o meses en tiempo real. No existían caminos ni otro medio de transporte que no fuera el caballo o la cansina carreta de bueyes. Las voces, por lo mismo, demoraban en comunicarse. Las cartas y representaciones se retardaban. Las ideas, sin embargo, crecían y se consolidaban localmente, en el corazón de cada pueblo. La "nación" colgaba entonces, en lo concreto, del lejano centralismo impuesto por el Rey y, en lo abstracto, de lo que pudieran hacer todos los pueblos, a futuro, a partir de la imagen de sí mismos.

Sobre ese archipiélago comunal pendían, sin embargo, nubarrones. Poderosas amenazas convergentes. especially the latter group, which tried to turn camaraderie into self-government (which emanated from the town council and not from the Captaincy General). Neighbourhood camaraderie, turned into democratic policy, reflected the reality of "towns", making it more important than the concept of "city" and their physical foundations. In each of these units, camaraderie was a mechanism for equality and democratic, local sovereignty. Therefore, every "town", before the establishment of the nation, was an important community nucleus.

By 1810, the year of independence, there were 50 towns distributed between the Huasco and Bío-Bio rivers. Each of them was separated by substantial space and time distances. The only means of transport were horses and the tiresome ox-drawn cart; roads did not exist yet. Also, communications were slow and letters delayed. However, despite this slowness, ideas grew and established in the heart of each town. Back then, the concept of "nation" depended literally on the distant centralism imposed by the King; but also depended figuratively on the eventual selfdetermination of all towns.

Nevertheless, a series of events threatened this social unit. 
Una de ellas era la multiplicación descontrolada de los mestizos en condición de niños "huachos" sin familia ni domicilio reconocido (por tanto, sin estatus de "vecino con casa poblada"). Careciendo de un Derecho Público adaptado a su condición dado que el Derecho Imperial englobaba sólo a los colonos hispánicos, a los criollos, a los indígenas y a los negroides esclavos -, los mestizos se hallaron, desde el principio, en situación de marginalidad integral, con la carga adicional del estigma oprobioso de su nacimiento. No formaron parte orgánica, en consecuencia, de los "pueblos" (salvo si se convertían en artesanos de chimba), razón por la cual engrosaron las anchas y largas alamedas de lo que fue el "bajo pueblo". La multiplicación del bajo-pueblo en condición de marginalidad generó una abundante población vagabunda, que deambuló de un lugar a otro (las fuentes hablan de "nubes de mendigos y merodeadores"), levantando ranchos dispersos en cualquier lugar. Colgando de los cerros. En lo hondo de las quebradas. Nunca se congregaron, por eso, como "pueblo". Nunca fueron identificados en posición de "ciudad". Ante eso, ninguna autoridad, a lo largo de tres siglos y medio (XVII, XVIII, XIX y la mitad del XX), pensó en reconocerlos como "ciudadanos". El sospechoso bajo-pueblo fue visto entonces como un pegajoso "enemigo interno". Eso significaba que era masacrable. De derechos violables.

Por eso, el "bajo pueblo" no tuvo ciudad ni por nacimiento ni por soberanía productiva. Ni por soli-
One of them was the uncontrolled proliferation of mixed-race orphans (who were not recognized as neighbours). Since they were not protected by Public Law -Imperial Law recognized Spaniards, Creoles, indigenous people and black slaves-, mixed-race people had to face social exclusion and the stigma of their origin. Also, since they were not part of "towns" (unless they were chimba artisans), mixed-race people constituted the "bajo pueblo" (low-class people). The increase of the bajo pueblo, under marginal conditions, generated a large amount of homeless people (documents speak of "clouds of beggars and prowlers") that settled anywhere; from hills to ravines. That is why they never organized as a "town" and they were never identified as part of the city. In face of this, no authority, during three and a half centuries (XVIIth, XVIIIth, XIXth and the half of the XXth centuries) regarded them as "citizens". The suspicious bajo pueblo was seen, then, as the "enemy within". They were criminals, they had no rights.

That is the reason the bajo pueblo was not part of the city -where neither birth nor productive sovereignty gave them the condition of citizens-. Solidarity and the Right to be citizen were not taken into account. Their "city" was, then, mobile, floating, poor and invasive. Indigenous people, at least, had their own territory and 
daridad ni por admisión a Derecho. Su 'ciudad' fue así inevitablemente móvil, flotante, nómade, precaria y, por tanto, invasiva. Los pueblos indígenas, al menos, tuvieron territorio propio y país hasta el segundo tercio del siglo XIX. La 'tierra' fue para los indígenas, por eso, su forma particular de 'ciudad'. Y la "frontera" de su territorio fue, por tanto, su suburbio. La chilenización forzada que el régimen portaliano impuso a partir de 1830 sobre todo el territorio que catalogó como 'nacional', desterritorializó la ciudad indígena y no territorializó la ciudad flotante de los mestizos. Tampoco reconoció la soberanía comunal de los 49 pueblos que no eran Santiago, pues el patriciado mercantil que predominaba en la capital (que heredó el control de todo el comercio exterior y el centralismo político de las jerarquías imperiales) terminó por imponerles a todos los pueblos una ciudadanía 'nacional' construida desde Santiago y a imagen y proyección del modelo ciudadano-súbdito dejado como recuerdo por la colonización española. Santiago fue, pues, la segunda amenaza que nubló el cielo de los 49 pueblos-ciudades que, durante uno o dos siglos, habían aprendido a auto-gobernarse en democracia comunal.

De una parte, el bajo-pueblo comenzó, poco a poco, a emigrar a los centros poblados: tenía que producir y vender sus productos para subsistir. Y prefirió, como es natural, bajar al más poblado de los pueblos: Santiago. Después que fue "pacificado" su territorio, los mapuches también se sumaron al were part of the country until the second third of the XIXth century. The "soil" was their particular concept of "city" and the suburb was the "frontier" of their territory. However, since 1830, the Portalian regime carried out a process of nationalization of territory, which left indigenous people without their soil and did not give a solution to the mobile city of mixedrace people. In addition, it did not recognize the communal sovereignty of the 49 towns that were not Santiago, as the merchant aristocracy (which inherited the control of foreign trade and political centralism from imperial hierarchies) forced all towns to accept the "national" citizenship built from Santiago. It was the extension of the citizensubject model used by the Spaniard colonizers. Santiago was, then, the second threat against the 49 towns-cities which had been self-governed during one or two centuries.

On the one hand, the bajo pueblo started gradually to emigrate to populated centres: it had to produce and sell its products in order to survive. And, naturally, it chose Santiago, the most populated city. Once their territory was "pacified", the Mapuche people joined the mixedrace movement. Thus, huts multiplied alongside the Mapocho river banks; down San Pablo street; on the periphery of Yungay neighbourhood; in Chuchunco; on Callejón de los Monos (Matta 
movimiento mestizo. Así, un rancho tras otro, por duplicación geométrica, fueron apareciendo en las riberas del Mapocho, por la calle San Pablo abajo, en la periferia del barrio Yungay, por Chuchunco, a lo largo del Callejón de los Monos (Avenida Matta), en los bordes de las Cañadas... Hacia 1840, los rancheríos (o "guangualíes") rodeaban Santiago por tres de sus cuatro costados. La ciudad flotante de los mestizos se materializó así, de pronto, en un gran "aduar africano" (Vicuña Mackenna) que se apretó en el cuello del conspicuo Barrio del Comercio (el cuadrilátero central). Y lo asfixió con sus tendales, sus baratillos, el humo de sus fraguas, hornillas y braseros, sus cabros chicos, el griterío de todos y las palabrotas de siempre.

De otra parte, el centralismo 'imperialista' de Santiago despojó a los pueblos de provincia, poco a poco, primero, de sus excedentes económicos; después, de su autonomía política (abolió los Cabildos, no creó asambleas provinciales e introdujo municipalidades centralizadas), para terminar arrastrando, primero a sus elites (que emigraron a Santiago hacia 1870 y 1880) y finalmente a la masa marginal que creció en el rezago de los pueblos así descremados. La victoria dictatorial de Santiago sobre las provincias (obra culminante del régimen portaliano) fue una victoria "a lo Pirro": todas sus víctimas terminaron agarrándose a su cuello. Pues todas ellas, bajo extorsión, habían dejado de ser "pueblo" en su patria (comunidad autónoma llena
Avenue); on the Cañadas... By 1840, the settlements (or "guangualies") surrounded Santiago on three of four sides. The mobile city of mixed-race people materialized -in words of Vicuña Mackenna- into an "African douar" that compressed the neck of the distinguished Barrio del Comercio (the main area). Their clothes airers and jumble sales; the smoke of their furnaces, stoves and braziers; their kids, the shouting and swearing eventually suffocated the illustrious zone.

On the other hand, the "imperialist" centralism of Santiago took away a series of elements from provincial towns. First, their economic surplus; then, their political autonomy (town councils were abolished and centralized municipalities were created instead of provincial assemblies); and finally their aristocracies (which emigrated to Santiago between 1870 and 1880) and the lower-class which lived on the remains of those towns. The dictatorial triumph of Santiago over provinces (the major achievement of the Portalian regime) was a Pyrrhic victory: all the victims were now in Santiago. All of them were no longer "town" in their own country (autonomous community with local camaraderie), they were now in a Big City, the concept of town was over... 
de complicidades locales) para aglomerarse en una Gran Ciudad que ya no podía ser pueblo..

Y la Gran Ciudad (portaliana) comenzó a defenderse contra sí misma. Vicuña Mackenna decidió salvar lo que llamó la "ciudad culta" (Santiago soñando París) desgajando de ella a la "ciudad bárbara" (los aduares de mestizos y marginales), creyendo que eran dos ciudades, e ignorando que Santiago, gracias al régimen pelucón, sería una Gran Ciudad Única para siempre. Y el dicho Intendente trazó el "Camino de Cintura" en los contornos y el Cerro Santa Lucía en su vértice. Pero fracasó: los plebeyos apenas se movieron y continuaron atiborrados dentro del anillo. Es que los "rentistas urbanos" estaban ganando mucho dinero arrendando sitios y "cuartos redondos" al invasivo bajo-pueblo. Al por menor y por metro cuadrado. Fue necesaria una segunda ofensiva: se ordenó construir una fachada urbanizada delante de los rancheríos. Se hizo, y surgió el "conventillo". La Ciudad, con él, perfeccionó un tanto sus peores líneas urbanísticas, pero eso significó que los plebeyos se quedaban para siempre. Además, multiplicándose ad infinitum dentro de los conventillos. Los rentistas urbanos se llenaron de dinero mestizo... La Iglesia Católica, viendo eso, conmovida, recomendó entonces construir casas decentes para los trabajadores, y vendérselas a precio módico. Se vendieron así casas de "cités" y de "poblaciones modelos". Pero el bajo-pueblo, ya arranchado por toda la Ciudad, era mucho. Demasiado para la caridad pública o
And the Big (Portalian) City started to defend against itself. Vicuña Mackenna decided to save what he called the "cultured city" (Santiago dreaming of Paris) by separating it from the "barbarian city" (the mixed-race and lowerclass douars), as he thought that Santiago was two units. What Vicuña Mackenna did not know was that Santiago, thanks to the pelucón (conservative) regime, would be a Big, Unique City forever. Thus, he built the "Camino de Cintura" (Waist Road) in the surroundings of the city -the Santa Lucia Hill was the vertex-. But it was a failure: the plebeians stayed where they were, living in crowded conditions. It was a profitable business for "urban renters", as they rented -by unit or by sq. m.- vacant lots and "cuartos redondos" (rooms with no windows) to the invasive bajo pueblo. Then, a second measure was needed: the construction of an urbanized facade to hide the settlements. It was the emergence of the tenement house. However, while this new kind of housing improved the urban design of the City, it meant that plebeians would stay forever. In addition, as lower-class people multiplied in the tenement houses, urban renters enjoyed their mixed-raced money... In the light of that situation, the Catholic Church suggested the construction of economical, decent houses for workers. In this way, "cités" (housing-estate) and 
privada. Se levantaron fábricas, se crearon más escuelas. Se prometió esto y lo otro. Fue inútil: las "nubes de mendigos, de obreros, de borrachos, de delincuentes, de prostitutas y, lo que fue peor, de subversivos" siguieron multiplicándose, hasta terminar adueñándose de nuevo, por completo, de la Gran Ciudad, incluso esgrimiendo proyectos socialistas y revolucionarios.

Llegamos así a 1918. Aparecieron monstruosas "marchas del hambre". Se creó la Asamblea Obrera de Alimentación Nacional, para darle un ultimátum al Presidente de la República. Los estudiantes universitarios ya se habían rebelado en 1906 y se habían sumado, casi desde el principio, a los subversivos y anarquistas. Y tuvieron su primer mártir: Domingo Gómez Rojas. Y los obreros de la $\mathrm{FOCH}$, los estudiantes de la FECH y los profesores de la AGPCH se unieron en 1925 junto a profesionales e industriales para organizar la Asamblea Constituyente de Asalariados e Intelectuales, con el fin de refundarlo todo: el Estado, la Sociedad, el Mercado, la Escuela y, por supuesto, el pueblo y la ciudad. No pudieron: los reprimieron y engañaron.

Pero la Gran Ciudad, definitivamente, estaba plebeyizada, sin vuelta. Los marginales habían tomado posesión del bastión parisino construido y defendido a balazos por el patriciado mercantil portaliano. Con una clara intención mestiza recolonizadora. "model town" houses were sold. Nevertheless, the number of the bajo pueblo people was too much; neither public nor private charity was able to provide a solution to them. Factories were built, schools were opened and promises were made. It was futile: the "clouds of beggars, workers, alcoholics, criminals, prostitutes and, the worst of all, subversives" continued multiplying until they took over the Big City; they even used socialist and revolutionary projects to that end.

By 1918, massive "hunger marches" were organized and The Workers' Assembly for National Nourishment was created to give the President an ultimatum. University students had rebelled in 1906 and joined subversive and anarchist groups; Domingo Gómez Rojas was the first martyr. In 1925, professionals, industrials and people belonging to the Federation of Chilean Workers, to the Students Federation of Universidad de Chile, and to the Association of Chilean Teachers, joined to create the Constituent Assembly of Wage Earners and Intellectuals. Their goal was to reorganize the State, the Society, the Market, the Education and the town and city as well. They were not able to do so. They were suppressed and deceived.

The Big City was irreversibly plebeianized. The lower-class people took possession of the Parisian 
Era demasiado. Fue entonces cuando la elite inició su fuga de la Gran Ciudad. Y abandonó sus palacios "cultos" (de calle Dieciocho, de la calle Ejército, de la Alameda, del Centro) a la chusma. A lo que viniera. Y se refugió, primero, en torno al cerro Santa Lucía. Y después en Providencia. Y más tarde en El Golf, en Vitacura, en Lo Curro, en Los Dominicos, en La Dehesa. Hasta chocar con las montañas. Y siempre fue seguida, paso a paso, tramo a tramo, por la chusma, por un ejército de nanas, por batallones de comerciantes minoristas, transportistas, taxistas, delincuentes y traficantes. La masa mestiza demostró ser leal, pegajosa e indesalojable de la espalda de la elite: tenía que trabajar, vender y comer. En su desesperación, la elite se enconchó como caracol, o como señores feudales en sus castillos, y construyó condominios con murallas, vigilantes y rondines. Con perros y alarmas eléctricas. Con miles de 'rubios' niños prisioneros en la eliticidad de sus colegios, en la elegancia globalizada de los malls, en el silencio conspicuo de los parques escondidos...

Nada parecía suficiente. El vértigo de la fuga elitaria arrastró la ciudad tras de sí, en ruta hacia el Este cordillerano. Y no sólo arrastró a la indispensable masa mestiza, sino también a los emulantes grupos medios que, sobre los escombros de las bajas mansiones abandonadas por sus dueños, están construyendo hoy sus departamentos en altura, gozosos de participar, por retirada de los antiguos propietarios, de los blasones, prestigios y temores bastion which had been built and fiercely defended by the Portalian merchant aristocracy.

It was then when the elite emigrated from the Big City. They left their "cultured" palaces (of Dieciocho and Ejército streets, of the Alameda and the Downtown) to the plebs and moved to the Santa Lucía hill area; and then to Providencia, El Golf, Vitacura, Lo Curro, Los Dominicos and La Dehesa, until the mountains stopped them. And they were always followed by the plebs, by an army of nannies, by battalions of small merchants, haulage contractors, taxi drivers, criminals and traffickers. The mixed-race people proved loyal and indissoluble from the aristocracy: they had to work, sell and eat. The upper-class, as in medieval times, built blocks of flats surrounded by walls and protected by guards, watchmen, dogs and electric alarms. In that environment, thousands of "blond" children are prisoners of the exclusive schools, the globalized smartness of malls, the distinguished silence of hidden parks...

Nothing seemed to be enough. In their escape towards the East, the aristocracy dragged the city with them. And just as the essential mixedrace people, the aspirational middle-class was also dragged. They are building flats over the remains of the mansions abandoned by their 
del barrio alto... Por eso, la elite de hoy, habiendo agotado las cimas habitables, perforó la cadena de cerros del norte de la capital, para escapar subrepticiamente, a lo largo de iluminados túneles de concreto, interponiendo decenas de peajes carreteros, a los bucólicos valles de Huechuraba, Chicureo, Liray y Colina... ¿Podrá allí tener, por fin, su requiescat in pacem (R.I.P.)?

Se han cumplido 200 años de vida republicana. Que son doscientos años de 'pueblos' que perdieron su autonomía, de 'bajo-pueblos' que quisieron ser ciudad y de una Gran Ciudad que ya no puede ser pueblo, sino fuga y persecusión.

Por lo tanto, el balance histórico neto que puede hacerse de estos 200 años es que no hay verdadera ciudad si no hay verdadero pueblo. Y que si no hay ni verdadera ciudad ni verdadero pueblo, postular que existe una verdadera 'nación' es, en lógica pura, un flatus vocis. Es esto lo que hay que celebrar para el Bicentenario.

El problema no es, pues, sólo el tipo de vivienda. O cómo mejorar a posteriori la estética urbanística de una Ciudad que se separa de sí misma al ritmo de una tocata y fuga en rabia y temor sostenido. Pues no se trata de extender los malls, las carreteras y los metros urbanos hasta donde vive, hacinado, el bajo-pueblo, que, aunque se ha apoderado de $3 / 4$ de la Ciudad, todavía no puede ser plenamente 'pueblo'; o sea, vecino confiable y reconocido con casa poblada, igual que todos sus vecinos. Ciudadano owners, enthused by the idea of reviving the past of the barrio alto (smart neighbourhood) ... That is why the elite, since there were no more habitable hills in the north of the city, decided to perforate them in order to escape, through illuminated, concrete tunnels and a series of toll motorways, to the bucolic valleys of Huechuraba, Chicureo, Liray and Colina... Will they finally find the eternal rest?

Chile is commemorating two hundred years of republican life. Two hundred years of "towns" that lost their autonomy, of "bajo-pueblos" that aspired to be part of the city, and a Big City that replaced the concept of town by those of emigration and pursuit.

Therefore, the balance of these two hundred years is that if there is no town, then there is no city. And following this premise, if there is neither a town nor a city, then the concept of "nation" is only nominal. That is all there is for commemorate the Bicentenary.

The kind of housing is not the problem. Neither is the improvement of the urban design of a city that is separating from itself. It is not about building malls, motorways and metro stations in zones where the bajo pueblo live, which, despite controlling three-fourths of the city, it cannot be "town". They cannot be trustworthy and 
integral, como todos sus vecinos. Pues ¿por qué se escapan las elites? ¿Por qué se atrincheran en sus herméticos condominios? ¿Por qué no quieren ser pueblo ni hacer ciudad?

El problema real es que no hemos construido una verdadera sociedad civil. No hemos hecho verdadera ciudadanía ni verdadera soberanía. Todavía estamos, en este sentido, a mediados del siglo XIX. Todavía bajo la concepción portaliana del librecomercio, del Estado liberal, del militarismo y la defensa anti-terrorista de las elites. Todavía estamos temerosos de los mestizos y de los indígenas. Todavía gobernados por colonos añorantes de la Europa globalizadora.

He ahí el verdadero problema. La ciudad no es verdadera ciudad si no es verdadero pueblo, como en el origen. Los arreglos cosméticos de la vivienda no pueden sanar las patologías del cuerpo social. La verdadera medicina, por tanto, empieza donde está el pueblo alienado de sí mismo, no la ciudad.

Gabriel Salazar Vergara recognized neighbours; they cannot be citizens. Why is the elite emigrating? Why are they entrenching themselves in their hermetic homes? Why are not they interested in the notions of town and city?

The problem is there is not a real civil society. The Portalian ideology of the XIXth century -defined by free-market, liberal State, militarism and elitist counterterrorism against plebs- is still influencing the concepts of citizenship and sovereignty. There is still fear of mixed-race and indigenous people and there are still leaders yearning for the globalizing Europe.

That is the root of the problem. The city is not complete if there is no town. Housing retouching is not enough to heal the pathologies of social body. Then, the cure to this disease is not in the city, but in the town.

Gabriel Salazar Vergara 